\title{
A Study on Pre-flowering Foliar Spray of Plant Growth Regulator on Growth and Yield Parameters in Sweet Pepper (Capsicum annuum L.) Under Protected Condition
}

\author{
Gurudayal Sahu ${ }^{1 *}$, Tarique Aslam ${ }^{2}$, Shubhashree Priyadarshinee Das ${ }^{2}$, \\ T.K. Maity ${ }^{2}$ and N.K. Gupta ${ }^{1}$ \\ ${ }^{1}$ Department of Horticulture, College of Agriculture, RVSKVV Indore- 452001, M.P, India \\ ${ }^{2}$ Department of Vegetable Crops, Faculty of Horticulture, B.C.K.V., \\ Mohanpur -741252, W.B, India \\ *Corresponding author
}

\section{A B S T R A C T}

The present investigation entitled "Study of pre-flowering foliar spray of plant growth regulator on growth, yield and quality parameters in Sweet Pepper (Capsicum anпиum L.)

\begin{tabular}{|c|}
\hline Keywords \\
\hline $\begin{array}{l}\text { Capsicum, } \\
\text { growth regulator, } \\
\text { NAA, } \\
\text { Triacontanol. }\end{array}$ \\
\hline Article Info \\
\hline $\begin{array}{l}\text { Accepted: } \\
\text { 29 June } 2017 \\
\text { Available Online: } \\
\text { 10 July } 2017\end{array}$ \\
\hline
\end{tabular}
Under protected condition" was carried out during the year 2013-2014 at Hi-tech horticulture unit of Department of Horticulture, College of Agriculture, Indore, Rajmata Vijayaraje Scindia Krishi Vishwa Vidyalaya, Gwalior (M.P.). The experimental material for the present investigation was comprised of nine treatments viz. GA3 (10 and $50 \mathrm{ppm}$ ), NAA (10 and $50 \mathrm{ppm}), \mathrm{CCC}$ (5 and $10 \mathrm{ppm})$ and Triacontanol (5 and $10 \mathrm{ppm})$ are utilized for comparative study. These treatments are laid in Completely Randomized Block Design with three replications. Observations were recorded on the basis of five random competitive plants selected from each plot separately for morphological, growth analytical, phenological, and yield parameters were evaluated as per standard procedure and also estimate the economics. The results found that foliar application of NAA and Triacontanol has significantly increase growth as well as yield attributes. However, growth retardant like cycocel reduced plant height and hence causing dwarfness to the plant. Among the different plant bio- regulators treatments tried, the foliar application of NAA at concentration of 10 and $50 \mathrm{ppm}$, whereas Triacontanol at concentration of 5 and $10 \mathrm{ppm}$, was found to be better alternatives for boosting, up the production of sweet pepper cv. Pusa Deepti under protected cultivation.

\section{Introduction}

The genus Capsicum belongs to the family Solanaceae which is grown in several parts of the world and is believed to be native of Tropical South America. The domesticated peppers could be broadly classified into sweet and hot types based on their level of pungency. The bell pepper (Capsicum annuum L. var. grossum Sendt; $2 \mathrm{n}=24$ ) is commonly known as sweet pepper, capsicum or green pepper. They differ from common hot peppers in size and shape of the fruits, capsaicin content and usage. Bell pepper is one of the highly remunerative vegetables cultivated in most parts of the world especially in temperate regions of Central and South America and European countries, tropical and subtropical regions of Asian continent. In the world, area and production 
of bell pepper is merged with that of hot pepper (chilli pepper). Total world production of capsicum was 36.46 million metric tonnes from an area of 2.12 million hectare. China is the major producer of capsicum and contributes 36 per cent of the worlds cultivated area with a production of 12.53 million tonnes. India contributes average annual production of 0.9 million tonnes from an area of 1.85 million hectare with a productivity of 1.8 tonnes per ha (Anon., 2012).

There are many cultivars of sweet pepper exhibiting vide variation in size, shape and colour of fruit. The colour of fruits varies from dark green to yellow and their shape varies from small conical to thick blocky or flattened. Nutritionally, 100gm of edible portion of capsicum provides vitamin $180 \mathrm{IU}$, energy $24 \mathrm{Kcal}$, protein $1.3 \mathrm{~g}$, carbohydrate $4.3 \mathrm{~g}$ and fat $0.3 \mathrm{~g}$. It also finds place in preparations like pizza stuffing's and burger with growing popularity of fast food. The high market price is attributed to the heavy demand from the urban consumers. There is a good demand for export too.

The export market needs fruits with longer shelf life, medium size tetra lobed fruits with attractive colour, mild pungency with good taste. However the supply is inadequate due to the low productivity of the crop. Hence, there is necessity to improve vegetable production in India.

The maximization of produce and productivity per unit area of vegetable can be achieved by having integration of necessary efforts like use of improved cultivar and adopting various agro- techniques. The search for new avenues has led to development of Hi-Tech precision agricultural systems. Polyhouse, the latest word in Indian agriculture is one such means, where the plant are grown under controlled or partially controlled environment resulting in higher yields than that is possible under open conditions.

Plant growth regulators (PGRs) are organic compounds, other than nutrients that modify plant physiological processes. PGRs, called biostimulants or bioinhibitors act inside plant cells to stimulate or inhibit specific enzymes or enzyme systems and thus regulate plant metabolism. They normally are active in low concentrations in plants. About sixty plant regulators are commercially being used and several of them have reached considerable importance in crop production. Among the plant bio-regulators, the effect of auxins, gibberellins has already been proved. Retardants like CCC are known to control excessive biomass production and they produce their effects through changing the internal levels of the naturally occurring hormones, thereby, causing a modification of growth and development in the desired direction and to the desired extent. Triacontanol has been recently proved to improve the yield without morphological alteration. Though the plant growth regulators have great potentialities to influence plant growth and morphogenesis, its application and actual assessments etc. have to be judiciously planned in terms of optimal concentrations, stage of application, species specificity, seasons, etc. which constitute the major impediments in PGRs applicability. In view of their wide spectrum effectiveness on every aspect of plant growth, even a modest yield in capsicum.

\section{Materials and Methods}

The present experiment was carried out at the Hi-tech Horticulture unit of the Department of Horticulture, College of Agriculture Indore (M.P.). The experimental material for the present investigation was comprised of nine treatments viz. GA3 (10 and $50 \mathrm{ppm}$ ), NAA (10 and $50 \mathrm{ppm}), \mathrm{CCC}$ (5 and $10 \mathrm{ppm}$ ) and 
Triacontanol (5 and $10 \mathrm{ppm}$ ) are utilized for comparative study. These treatments are laid in Completely Randomized Block Design with three replications. Observations were recorded on the basis of five random competitive plants selected from each plot separately for morphological, growth analytical, phenological and yield parameters were evaluated as per standard procedure and also estimate the economics.

\section{Results and Discussion}

\section{Morphological and growth analytical parameters}

Various treatments showed significant variation in growth attributes viz., plant height, number of branches, spread of the plant, and stem thickness, number of leaves per plant, dry weight of leaves and leaf area (Table 1). The data revealed that these parameters in general progressively increased with the increase in age of crop. At 120 DAT, the plant height, number of branches, stem thickness, number of leaves per plant and leaf area increased significantly by different treatment of GA3, NAA, CCC and Triacontanol. The highest plant height (72.03 $\mathrm{cm})$, maximum numbers of branches (13.60), maximum number of leaves (113.25) were found by application of NAA @ 50 ppm (T4). The maximum leaf area $(23.75 \mathrm{~cm})$ is found with foliar spray of GA3 @ 50ppm (T2), whereas the maximum stem thickness (1.21 $\mathrm{cm}$ ) was found in treatment T6 (CCC 10 ppm).

The application of NAA @ 50 ppm produced taller plants $(30.87,41.00,60.93$ and 72.33$)$ at all the stage of plant growth which was followed by T3. There is a significant variation in plant height at all phases of growth due to effect of different plant bioregulators. At all stages of growth, NAA showed significantly greater plant height than other treatment. An increase in the plant height due to the growth regulators could be attributed to an increase in the meristematic activity of apical tissues. Growth regulators are involved in increasing photosynthetic activity, efficient translocation and utilization of photosynthates causing rapid cell elongation and cell division at growing region of the plant leading to stimulation of growth, besides increasing the uptake of nutrients (Dicks, 1980). Another probable reason may be due to the oxidative decarboxylation of synthetic auxins which could be catalyzed by the enzyme peroxidase (Reinecke and Bandurski, 1987). The present finding of plant height are supported by the finding of Singh et al., (2012) who noted the increasing in plant height with application of different concentration of auxin as foliar sprays (NAA $50 \mathrm{ppm})$ in capsicum under protected condition in Garhwal region, Himachal Pradesh. Findings corroborates with their results obtained by Salas et al., (2009), Kannan (2009), Kubal (1999), Vaishampayan (1997), Singh and Lal (1994) and Pandita et al., (1989). Applications of CCC (5 and 10 ppm) have dwarfing effect on the plant. The mechanism of reduction in plant height due to application of CCC appears to be due to slowing down of cell division and reduction in cell expansion. Thus, the reduced plant height is due to retardation of transverse cell division particularly in cambium, which is the zone of meristematic activity at the base of the internode (Grossman, 1990).

The finding of NAA @ 50 ppm (T4) was the most effective treatment in producing lateral branch (2.80,5.60,10.37 and 13.37) at all stage, which was at par with T7 (5.20) at 60 DAT and T7 (12.07) at 90 DAT and T3 (12.04) at 120 DAT. It was observed that numbers of branches are directly correlated with height of the plant. The finding of number of branches is also agreement with the finding of Kubal (1999) who observed 
that the more number of branches as compared to control in capsicum under Konkan condition with foliar spray of NAA at the rate of $20 \mathrm{ppm}$. Pandita et al., (1989) observed produced the highest number of branches in chilli plant by spraying of NAA twice at the rate of $10 \mathrm{ppm}$. Findings also corroborates with their results obtained by Prabhu Desai (1985), Singh (2012) and Sridhar (2009).

The foliar application of NAA@ 50 ppm (T4) produced maximum number of leaves (113.25) was observed at 120 days. Similarly NAA 10ppm (T3) produced 12.52, T8 (55.22) at 60 DAT and T8 (95.51) at 90 DAT. At every growth phase, there was increase in number of leaves per plant.

It was noticed that, there was rapid increase in number of leaves during 30 to 60 days period. In general, leaf is considered as an important functional unit of plant which contributes to the formation of yield. The numbers of leaves were maximum at 120 DAT and declined later due to shedding. The least number of leaves were produced under treatment $\mathrm{T} 2$ (GA3 $50 \mathrm{ppm}$ ) at all growth phases (10.60, 43.45, 84.97, 87.84).

The finding was similar to Vaishampayan (1997) who reported that NAA @ 25 ppm increased number of leaves in capsicum and chilli crop under Konkan condition. Miniraj and Shamugavelu (1987) recorded maximum number of leaves in chilli plant treated with 2 ppm Triacontanol under South Indian condition. The results compared with present finding are analogous with the finding by Sridhar (2009), Kubal (1999), Kannan (2009) and Singh (2012), who also recorded increased number of leaves per plant in chilli by application of NAA and Triacontanol.

In the present study, the leaf area increased 90 DAT and decreased thereafter due to senescence and ageing of leaves. In general, the application of growth regulators showed a profound effect over these parameters and significant differences were noticed among the growth regulator treatments at all the growth stages (Table 3). The maximum leaf area $\left(23.75 \mathrm{~cm}^{2}\right)$ was found in the application of GA3 @ 50 ppm followed by GA3 @ 10 ppm. The treatment showed significant effect on leaf area. In general, it was observed that there was increase of leaf area with increasing concentration of GA3. The finding of leaf area is agreement with the finding of Sultana et al., (2006) who reported that the highest leaf area index (LAI) produced by GA3 at 50 ppm.

The maximum stem thickness was recorded by the use of CCC @ both 5 and 10 ppm concentration. It clearly shows that as plant height decrease stem become thicker. CCC impose dwarfness to the plant as compared to control but same time increased the stem diameter. This is supported by finding of Gollagi et al.,(2009) who observed that Cycocel treatment increased stem diameter in chilli cv. Byadagi Kaddi under south Indian condition. Findings corroborates with their results obtained by Sinha et al., (1978).

\section{Days to flowering}

The foliar sprays of GA3 @ 50ppm (T2) produced the first flowering at 40.56 DAT as against at 41.33 DAT in control (Table 2). Further, the same treatment was found to exhibit earlier '50 per cent flowering' (43.40 DAT) as compared to control (46.83).

The plant bio regulators showed significant effect on first flowering, 50 per cent flowering and number of flowering per plant. This induction of flowering is may be due to the fact that GA act as a 'florigen' or enable the production and transport of other signals. It was also reported earlier that GA plays an important role in promotion of flowering in some plants (King et al., 2006). 


\section{Int.J.Curr.Microbiol.App.Sci (2017) 6(7): 3998-4007}

Table.1 Effect of different treatments of plant growth regulators on morphological and growth analytical Parameters of sweet pepper Cv.Pusa Deepti

\begin{tabular}{|c|c|c|c|c|c|c|c|c|c|c|c|c|c|c|c|c|c|}
\hline Treatments & Plant 1 & ght $(\mathrm{cm}$ & & & No. & branc & & & Numbe & of leaves & & & Leaf a & $\mathrm{ea}(\mathrm{cm} 2$ & & & Stem \\
\hline & $\begin{array}{l}30 \\
\text { DAT }\end{array}$ & $\begin{array}{l}60 \\
\text { DAT }\end{array}$ & $\begin{array}{l}90 \\
\text { DAT }\end{array}$ & $\begin{array}{c}120 \\
\text { DAT }\end{array}$ & $\begin{array}{l}30 \\
\text { DAT }\end{array}$ & $\begin{array}{c}60 \\
\text { DAT }\end{array}$ & $\begin{array}{l}90 \\
\text { DAT }\end{array}$ & $\begin{array}{c}120 \\
\text { DAT }\end{array}$ & $\begin{array}{l}30 \\
\text { DAT }\end{array}$ & $\begin{array}{c}60 \\
\text { DAT }\end{array}$ & $\begin{array}{l}90 \\
\text { DAT }\end{array}$ & $\begin{array}{c}120 \\
\text { DAT }\end{array}$ & $\begin{array}{c}30 \\
\text { DAT }\end{array}$ & $\begin{array}{c}60 \\
\text { DAT }\end{array}$ & $\begin{array}{l}90 \\
\text { DAT }\end{array}$ & $\begin{array}{c}120 \\
\text { DAT }\end{array}$ & $\begin{array}{l}\text { girth } \\
(\mathrm{cm})\end{array}$ \\
\hline T1-GA3 $10 \mathrm{ppm}$ & 25.73 & 35.53 & 37.67 & 39.00 & 1.60 & 3.60 & 5.57 & 8.77 & 12.42 & 44.78 & 84.87 & 87.97 & 12.05 & 13.12 & 22.42 & 25.48 & 0.85 \\
\hline T2-GA3 $50 \mathrm{ppm}$ & 24.67 & 34.40 & 38.30 & 40.21 & 1.33 & 3.13 & 4.63 & 7.97 & 10.60 & 43.45 & 84.93 & 87.84 & 13.04 & 16.47 & 23.96 & 28.05 & 0.85 \\
\hline $\begin{array}{l}\text { T3-NAA } 10 \\
\text { ppm }\end{array}$ & 30.13 & 38.00 & 57.40 & 61.50 & 2.40 & 5.73 & 12.00 & 12.04 & 14.52 & 53.70 & 91.03 & 106.93 & 11.32 & 14.65 & 18.63 & 20.50 & 0.85 \\
\hline T4-NAA $50 \mathrm{ppm}$ & 30.87 & 41.00 & 60.93 & 72.33 & 2.80 & 5.60 & 12.37 & 13.67 & 13.25 & 52.58 & 93.67 & 113.25 & 10.86 & 14.87 & 21.44 & 21.44 & 0.84 \\
\hline T5-CCC 5ppm & 29.73 & 34.47 & 36.93 & 37.50 & 2.00 & 4.27 & 7.23 & 9.67 & 13.43 & 46.85 & 79.70 & 85.92 & 11.34 & 15.23 & 19.14 & 22.93 & 1.15 \\
\hline T6-CCC 10ppm & 30.47 & 33.73 & 35.90 & 36.50 & 2.53 & 5.20 & 9.60 & 9.78 & 12.40 & 46.03 & 82.52 & 91.85 & 13.23 & 17.52 & 23.11 & 25.18 & 1.21 \\
\hline $\begin{array}{l}\text { T7-Triacontanol } \\
5 \mathrm{ppm}\end{array}$ & 27.67 & 35.13 & 52.07 & 60.33 & 1.87 & 5.20 & 12.07 & 12.00 & 13.24 & 53.27 & 93.60 & 107.39 & 12.42 & 5.47 & 19.25 & 23.79 & 0.95 \\
\hline $\begin{array}{l}\text { T8-Triacontanol } \\
10 \mathrm{ppm}\end{array}$ & 27.93 & 31.50 & 53.69 & 55.67 & 2.53 & 4.53 & 11.47 & 11.92 & 12.22 & 55.22 & 95.51 & 109.75 & 10.87 & 14.78 & 17.33 & 23.69 & 0.90 \\
\hline T9-Control & 30.00 & 35.33 & 52.10 & 60.50 & 2.27 & 4.53 & 9.97 & 11.00 & 12.96 & 56.45 & 89.99 & 106.48 & 12.30 & 13.54 & 18.14 & 22.64 & 0.92 \\
\hline $\mathrm{SE} \pm$ & 3.66 & 3.39 & 5.28 & 5.95 & 1.13 & 1.08 & 1.07 & 2.02 & 1.34 & 1.83 & 1.09 & 2.44 & 0.35 & 0.48 & 0.54 & 0.76 & 0.02 \\
\hline $\mathrm{CD}(\mathrm{P}=0.05)$ & NS & 7.21 & 11.24 & 12.67 & NS & 2.30 & 2.28 & 4.30 & 2.86 & 3.90 & 2.32 & 5.20 & 1.14 & 1.37 & 2.14 & 1.61 & 0.05 \\
\hline
\end{tabular}


Table.2 Effect of different plant growth regulators on number of days to first flowering, $50 \%$ flowering and number of flowers per plant, days to first fruit set, $50 \%$ fruit set and number of fruits per plant of sweet pepper Cv.Pusa Deepti

\begin{tabular}{|c|c|c|c|c|c|c|c|}
\hline Treatments & $\begin{array}{l}\text { Days for first } \\
\text { flowering }\end{array}$ & $\begin{array}{l}\text { Days for } 50 \text { percent } \\
\text { flowering }\end{array}$ & $\begin{array}{l}\text { Number of } \\
\text { flowers per plant }\end{array}$ & $\begin{array}{l}\text { Days to first } \\
\text { Fruit set }\end{array}$ & $\begin{array}{l}\text { Days to } 50 \% \\
\text { fruit set }\end{array}$ & $\begin{array}{l}\text { Number of } \\
\text { fruits per } \\
\text { plant }\end{array}$ & $\begin{array}{l}\text { Percent } \\
\text { fruit set }\end{array}$ \\
\hline T1-GA3 10 ppm & 46.37 & 46.13 & 17.83 & 56.59 & 64.51 & 12.32 & 57.01 \\
\hline T2-GA3 $50 \mathrm{ppm}$ & 40.57 & 43.40 & 18.77 & 53.73 & 63.57 & 12.74 & 54.45 \\
\hline T3-NAA 10 ppm & 41.40 & 45.60 & 19.56 & 57.01 & 61.81 & 13.97 & 56.59 \\
\hline T4-NAA $50 \mathrm{ppm}$ & 41.37 & 44.70 & 17.68 & 54.45 & 61.10 & 14.21 & 53.73 \\
\hline T5-CCC 5ppm & 42.00 & 46.00 & 22.85 & 54.97 & 60.12 & 17.88 & 54.97 \\
\hline T6-CCC 10ppm & 40.60 & 48.00 & 23.89 & 53.61 & 59.43 & 17.98 & 53.61 \\
\hline T7-Triacontanol 5ppm & 47.20 & 51.43 & 26.22 & 59.24 & 62.58 & 20.43 & 59.24 \\
\hline T8-Triacontanol 10ppm & 43.20 & 47.31 & 27.49 & 57.91 & 63.26 & 22.27 & 57.91 \\
\hline T9-Control & 41.33 & 46.84 & 17.40 & 57.82 & 64.18 & 13.14 & 57.82 \\
\hline $\mathrm{SE} \pm$ & 0.38 & 1.92 & 0.87 & 1.90 & 0.71 & 2.17 & 1.90 \\
\hline $\mathrm{CD}(\mathrm{P}=0.05)$ & 0.82 & 4.11 & 1.86 & 4.04 & 1.51 & 4.62 & 4.04 \\
\hline
\end{tabular}

Table.3 Effect of different plant growth regulators on fruit and fruit yield parameters of sweet pepper Cv.Pusa Deepti

\begin{tabular}{|c|c|c|c|c|c|c|c|c|}
\hline Treatments & $\begin{array}{l}\text { Fruit length } \\
(\mathrm{cm})\end{array}$ & $\begin{array}{l}\text { Fruit } \\
\text { diameter } \\
(\mathrm{cm})\end{array}$ & $\begin{array}{l}\text { Fruit } \\
\text { Volume } \\
\text { (cc) }\end{array}$ & $\begin{array}{l}\text { Fruit } \\
\text { weight } \\
\text { (g) }\end{array}$ & $\begin{array}{l}\text { Seed } \\
\text { weight } \\
\text { per fruit(g) }\end{array}$ & $\begin{array}{l}\text { Yield } \\
\text { (q/ha) }\end{array}$ & $\begin{array}{l}\text { Yield/plot } \\
\text { (kg) }\end{array}$ & $\begin{array}{l}\text { Yield/plant } \\
\quad(\mathrm{kg})\end{array}$ \\
\hline T1-GA3 $10 \mathrm{ppm}$ & 9.19 & 4.57 & 54.03 & 59.19 & 1.43 & 47.31 & 14.47 & 0.73 \\
\hline T2-GA3 $50 \mathrm{ppm}$ & 8.70 & 4.40 & 57.04 & 63.03 & 1.60 & 50.07 & 15.85 & 0.80 \\
\hline T3-NAA 10 ppm & 7.70 & 4.33 & 53.66 & 60.26 & 1.62 & 53.84 & 16.10 & 0.84 \\
\hline T4-NAA $50 \mathrm{ppm}$ & 10.40 & 4.30 & 49.82 & 60.82 & 2.04 & 55.06 & 17.95 & 0.87 \\
\hline T5-CCC 5ppm & 8.66 & 4.65 & 57.00 & 54.53 & 1.59 & 61.42 & 19.22 & 0.96 \\
\hline T6-CCC 10ppm & 9.09 & 4.53 & 56.19 & 65.37 & 1.81 & 71.48 & 23.51 & 1.10 \\
\hline T7-Triacontanol 5ppm & 10.17 & 4.69 & 56.77 & 61.04 & 2.01 & 77.86 & 24.29 & 1.27 \\
\hline T8-Triacontanol 10ppm & 9.43 & 4.38 & 59.96 & 58.14 & 2.17 & 79.91 & 24.36 & 1.28 \\
\hline T9-Control & 10.21 & 4.58 & 60.17 & 58.10 & 1.86 & 48.45 & 15.26 & 0.76 \\
\hline $\mathrm{SE} \pm$ & 0.56 & 0.23 & 1.63 & 5.50 & 0.17 & 1.87 & 19.84 & 0.04 \\
\hline $\mathrm{CD}(\mathrm{P}=0.05)$ & 1.18 & NS & 3.47 & 11.70 & 0.36 & 3.99 & 12.16 & 0.10 \\
\hline
\end{tabular}


Triacontanol delayed flowering 4-6 days to that of controlled, but the maximum number of flower 27.49 were observed by the application of Triacontanol @ 10 ppm (T8), which may due to its role in providing an active ingredient for bud formation, bud development, and the improved quality of flowers (Reddy et al.,2002). The same trend of early flowering was supported by the finding of Narayan (1986), who found that 10 ppm GA3 sprayed flowered 6.33 days earlier to the control. Usha and Peter (1995) noticed that Triacontanol reduce the flower drop in chilli during summer. Thus, it leads to the significant increase in the number of flowers per plant. The results obtained are accordance with the findings of Choudhary et al., (2004), Sharma (1995), Ramanandan et al., (1991),Kannan (2009) and Yamgar and Desai (1987) with NAA and Triacontanol.

\section{Days to first fruit set and number of fruits per plant}

Application of CCC @ 10ppm (T6) set earliest fruit (53.61 DAT) and earliest 50\% fruit set (59.93 DAT) (Table 3). The highest number of fruits per plant (22.27) was produced by Triacontanol $10 \mathrm{ppm}$ (T8), which was followed by T7 (20.43). The highest fruit set $(59.24 \%)$ were obtained in $\mathrm{T} 7$ (Triacontanol 5ppm) followed by $\mathrm{T} 8$ $(57.91 \%)$. It was observed that there was reduction in duration required for first fruit set with high concentration of cycocel which was significantly earlier than other treatments. Fruit set under the influence of growth regulators might be due to activation of various internal mechanisms related with plant growth and metabolism. Grewal et al., (1993) reported that cycocel improves the translocation of photosynthates. This translocation improves filling of fruits with photosynthates and hence, induce early fruit set.The finding was supported by Sharma (1995), who obtained maximum number of fruits by spraying of Triacontanol at 4 weeks after transplanting in Tomato cv. Pusa Ruby under North Indian condition. The promotory effect of these bio- regulators on fruit set and number of fruits in solanaceous vegetable crops was observed by various research workers viz., Borowski (1999), Choudhary et al., (2004). Vaishampayan (1997) and Mamat et al., (1983).

\section{Fruit characters}

The maximum fruit length $(10.40 \mathrm{~cm})$ was observed by NAA (50 ppm) application, maximum diameter in T7 (4.69 CM), maximum fruit weight $\mathrm{T} 6(65.37 \mathrm{~g})$, whereas maximum fruit volume $(59.96 \mathrm{cc})$ and seed weight $(2.17 \mathrm{~g})$ were observed by the use of Triacontanol (10ppm) (Table 3). Triacontanol show promotory effect on fruit diameter, volume and seed weight. This is perhaps due to fact that Triacontanol hastens the cell elongation and division which result in increasing fruit size. The results obtained are in confirmed with the findings of Choudhary et al., (2004) who revealed that application of Triacontanol enhanced yield components (fruit volume, number of seeds per fruit, seed weight per fruit) in chilli cv. Suryamukhi as compared to control. Rise in fruit weight was also recorded by Warade (1997), Salas et al., (2009), Kubal (1999) and Kannan (2009).

\section{Yield of fruits (q/ha)}

The data regarding the effect of plant growth regulators on yield are given table 3 . Triacontanol (10 ppm) was found to be the most promising growth regulator $(79.91 \mathrm{q} / \mathrm{ha})$, followed by triacontanol @ 5ppm (77.85 q/ha) (Table 5). Similarly, Triacontanol (10 ppm) produced maximum yield per hectare $(79.91 \mathrm{q} / \mathrm{ha})$, per plot $(24.36 \mathrm{~kg})$ and per plant (1.28kg). Triacontanol has a stimulatory effect on photosynthesis and the increased growth and dry weight of plants treated with 
Triacontanol have been attributed to an improvement in photosynthesis and an enhanced accumulation of photosynthates. Chen et al., reported that higher transcription of the rbcS gene was associated with the improved photosynthetic activity in Triacontanol-treated plants. These authors also illustrated that Triacontanol affected photosynthesis by increasing the level and activity of ribulose-1, 5-bisphosphate carboxylase oxygenase (RuBisCO) and by improving the status of the photosystems. It has been demonstrated in a variety of plant species that the $\mathrm{CO}_{2}$ fixation rate increases when Triacontanol is applied in nano-molar concentrations. In similar way, the increase in yield may be attributed to several reasons such as increased uptake of nutrients, enhanced translocation of sugars and other metabolic activity in plant physiology. This may be due to application of Triacontanol, which might have resulted in higher accumulation of photosynthetic resulting in increase in yield. Morphologically, it can be attributed to increase in plant vegetative growth, reduction in flower and fruit drop, increase in fruit length, diameter and volume. The result obtained are in agreement with the findings of Kubal (1999) who reported that foliar spray of Triacontanol at $2.5 \mathrm{ppm}$ increased yield per plant as compared to control in capsicum under Konkan condition. The results obtained are in agreement with the findings of Borowaski (1999), Chaudhary et al., (2004), Kapitsimadi (1995) and Mamet et al., (1983).

From the present investigation it can be concluded that foliar application of NAA and Triacontanol has significantly increase growth as well as yield attributes. However, growth retardant like cycocel reduced plant height and hence causing dwarfness to the plant. Among the different plant bio- regulators treatments tried, the foliar application of NAA at concentration of 10 and 50 ppm,whereas
Triacontanol at concentration of 5 and 10 ppm, was found to be better alternatives for boosting, up the production of sweet pepper Cv. Pusa Deepti under protected cultivation.

\section{References}

Anonymous. 2011-12.Statistical status report, National Horticulture Board, Gurgaon (Haryana), India.

Borowski, E., Zbyszek, K. B. and Władysław, M. 1999. Effects of Tomatex /Triacontanol/ on chlorophyll fluorescence and tomato (Lycopersicon esculentum Mill.) yields. Biotechnology and physiology. 22(3): 271-274.

Chaudhary, B. R. 2004. Response of chilli (Capsicum annuum L.) to plant growth regulators. M.Sc. Thesis, Department of Horticulture, IAAS, Rampur, Chitwan, Nepal. pp. 81.

Dicks, J.W. (1980), Mode of action of growth retardants in research development on the use of plant growth retardants, British Plant Growth Regulator Group, Monograph, 4: 1-14.

Gollagi, S. G., Hiremath, S. M. and Chetti, M. B. 2009.Effects of growth regulator and nutrients on growth parameters and yield in chilli cv. Byadagi Kaddi. International Journal of Agricultural Sciences $5: 123-125$.

Grewal, H. S., Kolar, J. S., Cheema, S. S. and Sing, G. 1993. Studies on the use of growth regulators in relation to nitrogen for enhancing sink capacity and yield of gobhi sarson (Brassica napus). Ind. J. Plant Physiol., 36: 1-4.

Grossman, K. 1990. Plant retardants as tools in physiological research. Physiologia Plantarum, 78: 642-648.

Kannan K., Jawaharlal, M. and Prabhu, M. 2009. Auxins especially NAA had positive effect on plant growth, early flowering, yield and quality attributes. Agricultural Reviews 30(3):46-49. 
Kapitsimadi, C. and Vioryl, S. A. 1995. Effect of along chain alphatatic (Triacontanol) on growth and yield of different Horticultural Crops. Acta Hort. (ISHS) 379:237-244.

King, R. W., Moritz, T., Evans, L. T., Martin, J., Andersen, C. H., Blundell, C., Kardailsky, I. and Chandler, P. M. 2006. Regulation of flowering in the long-day grass, Lolium temulentum L., by gibberellins and the gene FLOWERING LOCUS T (FT). Plant Physiology 141, 498-507.

Kubal, S. L. 1999. Effect of growth regulators on growth and yield of sweet pepper [Capsicum annum var.grossum (L.)Sendt.].Cv.Colifornia Wonder and Hybrid 6 a M.Sc. (Agri.) thesis submitted to Konkan Krishi Vidyapeeth, Dapoli. (Unpublished).

Mamat, S.B., Fontenot, J. F. and Newsorn, D.W. 1983.The effect of Triacontanol on the growth and development of tobacco pepper. Hort. Sci.18 (2):110111.

Miniraj, N. and Shanmugavelu, K. G. 1987. Studies on the effect Triacontanol on growth, flowering, yield quality and nutrient uptake in chilies (Capsicum annum L.). South Indian Horticulrure. 35 (5):362-366.

Narayan, P. G. 1986. Effect of different levels of plant growth regulators on various agronomic traits in okra (Abelmoschus esculentus (L.) Moench). M.Sc. Thesis. Dr.Y.S.Parmar University of Horticulture \& Forestry, Nauni, Solan(H.P), India.

Pandita, M. L., Pandey, SC., Mangal, JK. and Singh, G. P. 1989. Effect of various concentrations of Planofix as foliar sprays in plant growth and fruit yield of chillies. Haryana J. Hort. Sci.9 (3 and 4): 170-174.

Prabhu Desai, VG. 1985. Effect of application of growth regulators on growth yield and quality of sweet pepper [Capsicum annum var.grossum (L.) Sendt.] Cv. Bharat (F1).A M.Sc. (Agri.) thesis submitted to Konkan Krishi Vidyapeeth, Dapoli. (Unpublished).

Ramanandam G., Sankar, C. Ravi and Reddy, D. S. 1991. Effect of growth regulators and potassium on flower types and fruit set in brinjal. Indian Journal of Horticulture, 48(1).64-70.

Reddy, B. O., Giridhar, P. and Ravishankar, G. A. 2002.The effect of triacontanol on micropropagation of Capsicum frutescens and Decalepis hamiltonii $\mathrm{W}$ \& A," Plant Cell, Tissue and Organ Culture, 71(3)253-258.'

Reinecke, D.M. and BandurskI, 1987, Auxin biosynthesis and metabolism. Plant hormones and their role in Plant Growth and Development, 24-42.

Salas, M. C., Fernandez, M. M. and Urrestaraz, M. 2009. Sweet pepper yield and fruit quality affected by different auxin application methods. Acta Horticulture. 807 (1): 401-406.

Salas, M. C., Fernandez, M. M., and Urrestaraz, M. 2009. Sweet pepper yield and fruit quality affected by different auxin application methods. Acta Horticulture. 807 (1): 401-406.

Sharma, S. K. 1995.Response of Triacontanol application certain morphological characters, fruit and seed yield and quality of tomato see. Ann. Agri Res. 16(1): 128-130.

Singh, D. K. and Lal, G. 1994. Use of plant growth regulators in chilli. Ann. Agri. Res. 15 (4): 485-488.

Singh, R. N., Pal, S. L., and Gusain, M. S. 2012. Effect of bio-regulators on growth and yield parameters of capsicum cultivars under controlled condition.HortFlora Research Spectrum, 1(1): 50-54.

Sinha R. P. 1978. Anatomical changes in capsicum annuum in response to 
gibberellic acid and cycocel. Journal of the Indian Botanical Society: 238-243.

Sridhar, G., Koti, R. V., Chetti, M. B.and Hiremath, S. M. 2009. Effect of foliar spray of naphthalene acetic acid [NAA] and mepiquat chloride [MC] on yield, physiological and biochemical parameters of bell pepper (Capsium annuum, cv. Tarihal Local) Journal of Agricultural Research (Pakistan),47(1); p. 3-652.

Sultana, W., Q. A. Fattah and Islam, M. S. 2006. Yield and seed quality of chilli (Capsicum Annum L.) as affected by different growth regulators Bagladesh J. Bot. 35(2): 195-197.
Usha, P. and Peter, K. V. 1995. Exogenous chemicals for increasing chilli production. Ind. Hort.40 (1): 44-45.

Vaishampayan, D. C. 1997. Effect of growth regulators, micronutrients complex and potassium on growth and yield of sweet pepper [Capsicum annum var.grossum, (L.) Sendt.] CV.California wonder. A M.Sc. (Agri.) thesis.

Warade, S. P. 1997. Effect of Planofix on control of flower drop and fruitset in chilli. Pesticides.11 (3):24-26.

Yamgar, V. T. and Desai, U. T. 1987. Effect of NAA and Planofix on flowering, flower and fruit drop and fruitset in chilli. J. Maharastra agri. Univ. 12(1):34-38.

\section{How to cite this article:}

Gurudayal Sahu, Tarique Aslam, Shubhashree Priyadarshinee Das, T.K. Maity and Gupta, N.K. 2017. A Study on Pre-flowering Foliar Spray of Plant Growth Regulator on Growth and Yield Parameters in Sweet Pepper (Capsicum annuиm L.) Under Protected Condition. Int.J.Curr.Microbiol.App.Sci. 6(7): 3998-4007. doi: https://doi.org/10.20546/ijcmas.2017.607.414 